Andrzej Stępniak

Maciej Zieliński

\title{
UNIA EUROPEJSKA JAKO PARTNER GLOBALNY. CO TO OZNACZA DLA POLSKI?
}

\begin{abstract}
Streszczenie
Artykuł prezentuje wyzwania, jakie stoją przed Unią Europejską i problemy, z jakimi musi sobie radzić $\mathrm{w}$ ostatnich latach, $\mathrm{w}$ kontekście swojej globalnej pozycji wśród innych sił politycznych i gospodarczych. Jest to próba odpowiedzi na pytanie o najważniejsze cechy, jakimi musi charakteryzować się UE, aby być traktowana jako partner globalny. Na tym tle zarysowany został możliwy udział Polski w reformie UE, a także jej obecna i przyszła pozycja w relacji ze Wspólnotą.

Słowa kluczowe: Unia Europejska, Polska, partnerstwo globalne, federalizm, potencjał militarny.
\end{abstract}

\section{Wstęp}

Unia Europejska bywa nazywana zarówno światowym mocarstwem, jak i globalnym partnerem, w zależności od kontekstu wypowiedzi. Czy jest to jednak uzasadnione, patrząc na siedem podstawowych fundamentów, które definiują globalnego gracza na arenie międzynarodowej? Zarówno pod kątem powierzchni, liczby ludności, jak i aspektów gospodarczych UE zajmuje czołowe miejsca w świecie. Jednak pozostaje kwestia jej silnej reprezentacji na zewnątrz oraz zdolności do obrony swojego terytorium. Ponieważ obecnie każdy z krajów członkowskich posiada własne siły zbrojne, a także prowadzi własną politykę międzynarodowa, są one traktowane $\mathrm{w}$ tych aspektach, na arenie międzynarodowej, w oderwaniu od struktur UE. A podkreślić należy, że samodzielnie żaden z krajów członkowskich nich nie ma możliwości osiąnięcia odpowiedniej pozycji na świecie, aby móc skutecznie konkurować z USA czy Chinami. 


\section{Współczesne wyzwania stojące przed Unią Europejską}

Aktualny obraz świata, jego polityki, gospodarki i sytuacji społecznej stawia przed Unią Europejską wiele wyzwań, które były trudne do przewidzenia $\mathrm{w}$ czasach, gdy ta organizacja powstawała. Niektóre $\mathrm{z}$ wydarzeń ostatnich lat były tak zaskakujące dla ekonomistów, polityków oraz obywateli, że mogliśmy obserwować narastającą nerwowość, poczucie dezorientacji i chaosu oraz powszechną niepewność. I choć niektórzy twierdza, że to sama UE jest źródłem wielu z tych problemów, to $\mathrm{w}$ praktyce należy podkreślić, że jedynie dzięki tej instytucji udaje się przezwyciężać największe problemy dzisiejszego świata, ponieważ kraje członkowskie w pojedynkę nie mogłyby udźwignąć ciężaru niektórych wydarzeń.

W aspekcie społeczno-ekonomicznym ostatnie lata przyniosły elektryzujący wszystkich temat migracji, zarówno tej zarobkowej wewnątrz UE, jak i tej związanej z "uchodźcami" spoza UE. Pierwsza wspomniana grupa, to ci emigranci, którymi podczas referendum ws. brexitu straszono obywateli Wielkiej Brytanii, czyli obywatele nowych krajów UE "przywłaszczający sobie" miejsca pracy, "okradający" system socjalny i "zabierający" chleb przeciętnym Brytyjczykom. $\mathrm{W}$ identycznym tonie wypowiadali się też niektórzy przedstawiciele aktywnych $\mathrm{w}$ ostatnich latach ruchów nacjonalistycznych w pozostałych krajach Europy, strasząc "falami przyjezdnych" z "biednych krajów" Unii. Z kolei drugą ze wspomnianych grup $\mathrm{w}$ dużej mierze stanowią przedstawiciele emigracji zarobkowej czy wręcz emigracji "bytowej", czyli takiej, która ma zapewnić lepsze warunki życia lub w ogóle to życie umożliwić tym, którzy żyją poniżej progu ubóstwa, dla których niejednokrotnie jest to wybór między poniżającym bytowaniem $\mathrm{w}$ obozach dla uchodźców po morderczej przeprawie przez Morze Śródziemne a całkowitym niebytem i śmiercią głodową. Ta liczna grupa emigrantów jest często umieszczana błędnie w jednej zbiorowości "uchodźców" z ludźmi uciekającymi przed konfliktami zbrojnymi w Afryce i na Bliskim Wschodzie, dla których migracja nie tylko ma na celu poprawę bytu ekonomicznego, ale jest inicjowana poprzez podstawowy instynkt przetrwania, szczególnie biorąc pod uwagę fakt, że w obecnych konfliktach zbrojnych ludność cywilna jest bardziej narażona na śmierć i kalectwo niż reprezentanci stron wojujących. Ten problem jest o tyle poważny, że silnie polaryzuje społeczeństwo europejskie i jest chętnie wykorzystywany przez ruchy narodowe i ich reprezentantów politycznych, co dodatkowo zaciemnia obraz sytuacji i utrudnia podjęcie istotnych działań $w$ tym obszarze.

Co istotne, abstrahując od strony politycznej czy społecznej, z czysto ekonomicznego punktu widzenia mamy do czynienia z coraz wyraźniejszym niedoborem siły roboczej w krajach zachodniej Europy, gdzie zaczyna brakować rąk do pracy i to już nie tylko do niskopłacowych prac fizycznych, ale także w handlu czy usługach. Problem ten obecnie jest już widoczny nawet $w$ takich krajach jak Polska czy kraje inne nadbałtyckie, chociaż powszechnie mówi się, że wszystkie 
te kraje mogą korzystać z zasobu pracowników ze wschodu. Aktualne raporty pokazuja że najgorsza sytuacja ma miejsce w Rumunii, gdzie niedobory wykwalifikowanej siły roboczej są szacowane aż na poziomie $81 \%$, a kolejne miejsca należą do Bułgarii (68\%), Grecji (61\%) oraz Słowacji (54\%). Pokazuje to wyraźnie, że nowe kraje UE, które miały być "źródłem" tańszej siły roboczej na wewnętrznym rynku, same obecnie cierpią na niedobory pracowników. Problemy mają także Polska (51\%), Węgry (51\%) i Portugalia (46\%). Sytuacja ta jednak nie dotyczy jedynie nowych czy biedniejszych krajów UE, ale także silnie rozwiniętych gospodarek, w których oferowane są wyższe wynagrodzenia i lepsze warunki pracy. Identyczny poziom niedoboru siły roboczej, jaki obserwuje się na Węgrzech czy w Polsce, dotknął w 2018 roku Niemcy (51\%), a kolejne w zestawieniu są Austria (46\%) i Szwecja (42\%), co pokazuje, że fala niedoboru pracowników "rozlewa się" powoli po całej Wspólnocie (ManpowerGroup, 2018). Unia Europejska ma ogromny dylemat, w ramach którego zdarza się negatywna propaganda, problem niezreformowanych systemów socjalnych czy lokalne przejawy nietolerancji rasowo-religijnej z potrzebami ekonomicznymi, niebezpiecznie niskim bezrobociem realnym $\mathrm{w}$ niektórych krajach członkowskich i powszechnie zwiększającym się deficytem demograficznym. Na to nakłada się także utrzymująca się zbyt niska mobilność pracowników w ramach Wspólnoty, ponieważ mimo "straszących" głosów organizacji narodowych i zwolenników rozwiązań separatystycznych, wiele wysoko rozwiniętych krajów UE potrzebuje pilnie pracowników z krajów, gdzie nadal utrzymuje się podwyższone bezrobocie, a problemu mobilności nie udało się rozwiązać od czasu wprowadzenia w UE czterech swobód podstawowych.

Kolejnym wyzwaniem na polu społeczno-ekonomicznym jest niski poziom wzrostu gospodarczego, a w przypadku niektórych krajów członkowskich, wręcz stagnacja w gospodarce. Świat w 2016 roku rozwijał się w tempie 2,4\% (analizując przyrost PKB rok do roku), a UE zanotowała jedynie 2-procentowy wzrost, co pokazuje, że obszar wspólnotowy rozwijał się wolniej niż światowa średnia (Eurostat, 2018). Dodając do tego burzliwą historię wspólnej waluty i problemy, z jakimi od czasu kryzysu zmagać się musi strefa euro, okazuje się, że wymagane są reformy, a także działania mające na celu z jednej strony stabilizację, a z drugiej strony zwiększenie znaczenia euro na świecie, poprzez dalsze rozszerzanie strefy. Problemem jest sposób dokonania tego przy zachowaniu europejskiego ducha wolności, który zabrania nacisków czy wymuszania na krajach członkowskich decyzji w sprawie przyjęcia wspólnej waluty. Ponadto, część nowych krajów UE nie jest jeszcze ekonomicznie ani społecznie gotowa na zmianę swojej własnej waluty na euro (Komisja Europejska, 2018). To istotne wyzwanie i problem, z jakim należy się jak najszybciej uporać. I w tym względzie widać już pewien zarys drogi, jaką kraje pretendujące do uczestnictwa w strefie euro powinny przejść, aby móc dołączyć do obecnych jej członków. Co więcej, powinno, a wręcz musi, się to odbyć z silnym wsparciem całej UE, aby odpowiednio przygotować 
grunt w każdym z krajów planujących przystąpienie do wspólnej waluty. A ten grunt należy przygotować zarówno na płaszczyźnie społecznej, jak i ekonomicznej, aby zwiększyć świadomość obywateli w zakresie korzyści płynących z posiadania euro, ale także zminimalizować ryzyko ewentualnych szoków w obszarze ekonomicznym.

Dążenia separatystyczne i wzrost aktywności ruchów narodowych to następne, niezwykle ważne, wyzwania, które stoją przed wszystkimi krajami kontynentu europejskiego. Najwięcej mówi się o potencjalnym "rozpadzie UE" w kontekście brexitu, jednak każde wydarzenia, nawet takie, z jakimi mieliśmy do czynienia w Katalonii, moga prowadzić w dalszej perspektywie do poważnych konsekwencji w kontekście integralności Wspólnoty. Źródła takich zdarzeń są bardzo zróżnicowane, niektóre obszary, na przykład Anglia, opowiedziały się za wystąpieniem ze Wspólnoty, z kolei sytuacja we wspomnianej Katalonii czy Szkocji lub w Gibraltarze pokazuje, że obywatelom jest bliżej do Europy niż do kraju, w skład którego obecnie wchodzą (z jednej strony część obywateli deklaruje chęć ogłoszenia niepodległości, jednocześnie chcąc pozostać jako nowy twór państwowy w ramach struktur europejskich). Jest to wyzwanie tym większe dla UE, im silniejsze głosy przemawiają za separatystycznymi działaniami takich regionów, gdyż w pewien sposób próbują zaangażować one UE w wewnętrzny konflikt $\mathrm{w}$ danym państwie, co z kolei mogłoby skutkować jeszcze większą falą krytyki ze strony tych, którzy niosą na sztandarach hasła o suwerenności państw wobec Wspólnoty. Stąd wydarzenia z tej kategorii muszą być traktowane $\mathrm{z}$ ogromną ostrożnościa, ponieważ wpływają na wizerunek UE i jej polityczną pozycję na świecie. Ponadto, nawet kraje o dojrzałej demokracji muszą zmagać się z tworami politycznymi bazującymi na ksenofobii i "straszeniu" obywateli brakiem suwerenności, napływem migrantów, „okradaniem” ich państwa przez UE czy zatracaniem świadomości historycznej poprzez zbyt silną integrację z sąsiadami. Niestety, coraz częściej powtarzane hasła zaczynają kiełkować w świadomości obywateli, co skutkuje niebezpiecznym trendem, w ramach którego partie o zabarwieniu narodowościowym, a nawet faszystowskim, osiagają $\mathrm{w}$ wyborach coraz lepsze rezultaty. Aby się temu przeciwstawić, zarówno lokalne partie proeuropejskie, jak i cała instytucjonalna machina UE powinny zaangażować się w kampanię informacyjną która będzie przełamywała rozsiewane kłamstwa i dezinformacje, jednocześnie edukując swoich obywateli. Jest to jednak również duży krok, na który musiałaby się zdecydować cała Wspólnota.

Spośród wyzwań, jakie stoją przed UE coraz ważniejsze wydają się wspólna polityka obronna oraz problemy militarne. Przez wiele lat temat ten był pomijany lub ignorowany. Dopiero rosyjska agresja na Ukrainie spowodowała, że poza niektórymi politykami europejskimi, także media i opinia publiczna wielu krajów UE zaczęły domagać się konkretnych ustaleń w tej materii. 


\section{Unia Europejska w roli globalnego partnera}

Bazując na wspomnianych już siedmiu podstawowych kryteriach, określających potęgę globalna, można przeanalizować każdy z nich, aby umieścić UE $\mathrm{w}$ odpowiednim kontekście na świecie. Pierwszym ważnym kryterium jest obszar, w przypadku UE to niemal 4,5 miliona kilometrów kwadratowych (Eurostat, 2016). Daje on Wspólnocie 7. miejsce na świecie pod względem zajmowanej powierzchni lądu. Ważny jest charakter tego obszaru. Wprawdzie większość zasobów naturalnych jest już na wyczerpaniu, ale jest to teren, na którym rodziła się zachodnia cywilizacja. Jest on niezwykle bogaty w zabytki, miejsca historyczne oraz świadectwa pochodzenia kultury i tradycji europejskiej, do dzisiaj będącej w centrum zainteresowania całego świata. Nawet mimo odbytych na kontynencie europejskim wojen, przetrwało wiele miejsc, które dzisiaj odwiedzają setki milionów turystów z całego świata. Taka kumulacja zabytków i dzieł sztuki, jaka występuje na terenie UE, nie ma konkurencji w żadnym innym kraju na świecie.

Kolejnym ważnym kryterium jest ludność. Pod tym względem UE zajmuje 3. miejsce $\mathrm{w}$ świecie, za Chinami i Indiami, stanowiąc miejsce zamieszkania dla ponad 512 milionów obywateli (Eurostat, 2018). Należy ponadto podkreślić, że znów nie sama tylko liczba mieszkańców jest imponująca, ponieważ mieszkańcy UE wykazują najwyższy udział osób wyedukowanych w całej populacji świata, a także, w zestawieniu z pięcioma najludniejszymi krajami świata, UE posiada najwyższy wskaźnik jakości życia (Europa.eu, 2017). Można zatem uznać, że ludność europejska posiada największy potencjał spośród obywateli wszystkich krajów świata. W odniesieniu do ekonomicznych kryteriów wysokiej pozycji globalnej, UE posiada $21,8 \%$ udziału w światowym PKB, ustępując jedynie USA, których udział w światowym PKB to $24,6 \%$. Na trzecim miejscu znalazły się Chiny z udziałem n poziomie 14,8\% w PKB całego świata (Eurostat, 2018).

Równie istotnym, jeśli nie istotniejszym, fundamentem pozycji kraju jako globalnego partnera, jest jego udział w światowym imporcie i eksporcie. Choć na ogół podaje się tę drugą wartość w aspekcie oceny siły gospodarczej czy potencjału produkcyjnego, to jednak udział $\mathrm{w}$ imporcie jest także istotny, ponieważ $\mathrm{w}$ globalnych relacjach partnerskich to kupujący ma często najsilniejszą pozycję. Udział UE w światowym imporcie to $14,8 \%$, czyli drugi wynik po USA, których udział to $17,6 \%$. Chiny ponownie zajęły trzecią pozycję z udziałem w wysokości 12,4\% (Eurostat, 2018). Światowa struktura eksportu kształtuje się nieco inaczej. $\mathrm{W}$ tym względzie nadal na czele stawki są Chiny z udziałem na poziomie $17 \% \mathrm{~W}$ światowym eksporcie, druga jest UE, której udział wynosi 15,6\%, a USA znajdują się na trzeciej pozycji z udziałem 11,8\% (Eurostat, 2018). Ostatnim z ekonomicznych aspektów mocarstwowości na arenie globalnej jest posiadanie silnej i stabilnej waluty, która ma odpowiednią pozycję na świecie. Choć nie wszystkie kraje członkowskie UE funkcjonują obecnie w strefie euro, to główna europejska waluta obecnie ustępuje jedynie dolarowi, jeśli chodzi o jej znaczenie w płatnościach 
globalnych, a różnica między tymi walutami zmniejsza się z roku na rok. Obecnie 39,9\% płatności odbywa się z wykorzystaniem USD, a 35,7\% z wykorzystaniem EUR. Także w innych sektorach obserwuje się systematyczny wzrost znaczenia EUR na świecie - większe rezerwy walutowe trzymane w EUR, większy udział pożyczek czy papierów dłużnych denominowanych w EUR itp. (Reuters, 2018; European Central Bank, 2018).

Pięć opisanych wyżej fundamentów globalnej pozycji UE spełnia, zajmując czołowe miejsca na świecie. Jednak prócz obszaru, ludności oraz elementów ekonomiczno-społecznych, należy pamiętać także o dwóch ostatnich kryteriach, które czynią dany kraj realną potęgą w skali globalnej. Chodzi tutaj o silną reprezentację zewnętrzną oraz efektywną politykę obronną. W obu tych aspektach Unię Europejską czeka jeszcze wiele działań. $W$ przeciwieństwie do fundamentów społeczno-ekonomicznych, przedstawionych wcześniej, zarówno siła militarna, jak i międzynarodowa rozpoznawalność i jedność w zakresie reprezentacji UE pozostają obszarami problematycznymi.

\section{Reprezentacja Unii Europejskiej na zewnątrz}

Chociaż w historii UE można wymienić kilka sytuacji, w których pojawiały się wizje federacyjnej Europy oraz budowy silnej wewnętrznej struktury czegoś na kształt "państwa europejskiego", to jednak do tej pory wszelkie zmiany idące $\mathrm{w}$ tym kierunku nie miały szans powodzenia. Było to spowodowane oporem jednego lub kilku członków Wspólnoty, gdzie rządząca w danym czasie opcja polityczna skutecznie hamowała szersze działania integracyjne. Do tej pory jedynym przejawem jednomyślności $\mathrm{w}$ zakresie kreacji wspólnotowych organów reprezentacji zewnętrznej było powołanie Wysokiego Przedstawiciela Unii Europejskiej do Spraw Zagranicznych i Polityki Bezpieczeństwa oraz zwiększenie kompetencji Przewodniczącego Rady Europejskiej po traktacie lizbońskim. Wykonano tym samym krok $\mathrm{w}$ dobrym kierunku, jednak na tym poprzestano. Obecna struktura i forma funkcjonowania Wspólnoty nie do końca się sprawdziła, istnieje więc konieczność podjęcia dalszych działań, które umożliwiłyby powołanie struktur europejskich o większych kompetencjach i o większym politycznym znaczeniu. Następnymi krokami byłoby zwiększenie wspólnotowego budżetu, aby umożliwił on finansowanie bardziej skoordynowanej polityki europejskiej i działań, jakie podejmowane byłyby z jednej strony na poziomie UE jako całości, a z drugiej strony bezpośrednio w regionach, wzmacniając wewnętrzną integrację i wysyłając w świat jasny komunikat o sile jedności Wspólnoty.

Należy także podkreślić, że UE, choć istnieje już od 25 lat, nie wypracowała w żadnego spójnego wizerunku na arenie światowej. W czasach, gdy wszystko jest oceniane "na pierwszy rzut oka" i często bez dodatkowej analizy, a liczba informacji docierających codziennie do człowieka wielokrotnie przekracza jego możliwości percepcyjne, sprawdzają się krótkie i jasne przekazy oraz odpowied- 
nio przygotowane działania marketingowe. Aby jednak móc je prowadzić, potrzebna jest jedna spójna polityka wizerunkowa, dotyczy to zarówno przedsiębiorstw, regionów, państw, jak i takich organizacji jak UE czy ONZ. Problemem jest tutaj legitymizacja władzy, ponieważ jedynie Parlament Europejski jest tym organem, którego członków wybierają obywatele w wyborach bezpośrednich, co daje mu bezpośredni mandat społeczny. Jednak wewnątrz UE realna władza leży przede wszystkim w rękach osób najczęściej wybieranych pośrednio na stanowiska szefów rządów czy ministrów państw członkowskich, co nie przysparza im wizerunku "wybranych przez naród europejski". W przyszłości może i ten stan rzeczy mógłby ulec zmianie. Warto przypomnieć, że w UE konflikt toczył się nawet wokół oficjalnego ogłoszenia flagi czy hymnu, ponieważ dla niektórych było to "otwarcie wrót" do stworzenia jednego organizmu państwowego, na co nie było jednomyślnej zgody. Takie sytuacje powoduja, że światowe mocarstwa, takie jak Chiny czy USA, nadal myślą o Europie jak o zbiorze osobnych państw, a nie silnej zbiorowości nadrzędnej, kreowanej przez Unię Europejską.

Amerykanie czy Azjaci myślą o Niemczech, Francji, Hiszpanii czy Szwecji, a nie o Europie jako całości. A ten brak wspólnego i jednoznacznego wizerunku nie wzmacnia europejskiej pozycji negocjacyjnej w świecie, ale ją osłabia, sprowadzając ją jedynie do siły najsilniejszego ogniwa, nie zaś do siły, jaką daje suma wszystkich składników. Naraża to także UE na negatywne skutki ewentualnych problemów poszczególnych państw członkowskich, jak na przykład miało to miejsce w pokryzysowej rzeczywistości, jaka dotknęła Grecję czy Irlandię. Dzisiaj problem jednego członka UE to problem całej UE, przekładający się na spadek zaufania inwestorów, deprecjację euro czy wzrost rentowności obligacji. A przecież, gdyby UE stanowiła bardziej jednolity organizm, nawet w przestrzeni wizerunkowej, to sytuacja wyglądałaby zgoła inaczej. Przecież zła sytuacja ekonomiczna wschodnich województw Polski nie rzutuje jednoznacznie na postrzeganie całego państwa na arenie międzynarodowej. Nikt na świecie, patrząc na Francję, nie zastanawia się, czy któryś z jej regionów jest na skraju bankructwa czy ma nadwyżki w budżecie lokalnym. Oceniane jest państwo jako całość, analizowane są wskaźniki dotyczące całej gospodarki, a lokalne dane nie są tak istotne, szczególnie z perspektywy globalnej. Podobne korzyści z jednolitego wizerunku mogłaby czerpać UE, o ile taki jednolity wizerunek udałoby się jej zbudować. Wtedy świat nie skupiałby się tak bardzo na problemach indywidualnych państw członkowskich (co umożliwiłoby z kolei szybsze poradzenie sobie z ewentualnymi ich reperkusjami), ale oceniałby sytuacją UE jako całości, co zwiększałoby stabilność inwestycyjną i otwierałoby całkiem nowe perspektywy rozwoju dla całej Europy. 


\section{Siła militarna oraz potencjał obronny Unii Europejskiej}

Pierwsze plany stworzenia wspólnej formacji zbrojnej sięgają niemal samych korzeni UE, jednak klimat polityczny, jaki jest potrzebny do wprowadzenia w życie tak odważnych decyzji nadszedł dopiero po rozpoczęciu konfliktu zbrojnego na Ukrainie. Coraz częściej w mediach oraz wśród polityków oraz zwykłych obywateli UE zaczęto podnosić problem braku skoordynowanych i działających wspólnie sił zbrojnych Europy. Siła gospodarcza UE jest niepodważalna, jednak Wspólnota nie dysponuje żadną skonsolidowaną zdolnością obronną na wypadek ataku z zewnątrz. Obecnie jest to jedynie pewnego rodzaju suma składowych, obejmujących wojska poszczególnych krajów członkowskich. Jednak jest to klasyczny przykład, gdy suma składowych jest $\mathrm{w}$ praktyce niższa niż wskazywałaby na to arytmetyka. Ponieważ nie można bezrefleksyjnie dodać wszystkich wartości liczbowych, jakimi charakteryzują się poszczególne armie, gdyż w przypadku ewentualnego konfliktu zbrojnego nie mają one jednego wspólnego dowództwa, pozbawione są możliwości odpowiedniej koordynacji działań. Dodatkowy problem stanowią niekompatybilne uzbrojenie, różniące się metody wyszkolenia żołnierzy czy nieusystematyzowany system rang. Stąd jeden silny agresor, działający w sposób przemyślany, może dysponować nawet o połowę mniejszym potencjałem, jednak stanowić będzie większe zagrożenie niż połączone siły poszczególnych europejskich armii. A jednak potencjał UE jest w tym względzie znaczny. Teoretyczne wartości, wynikające z sumy posiadanych przez państwa członkowskie UE sił militarnych, potrafią rozbudzić wyobrażenie o tym, jak mogłaby wyglądać europejska armia. Według danych za rok $2018 \mathrm{w}$ państwach Wspólnoty służy ponad 1,6 miliona aktywnych zawodowo żołnierzy, co daje drugi po Chinach (ok. 2,2 mln) wynik na świecie, w tyle zostawiając zarówno Indie (ok. 1,4 mln), USA (ok. 1,3 mln) i Rosję (ok. $1 \mathrm{mln}$ ).

Tabela 1. Porównanie największych światowych sił militarnych i UE [szt.]

\begin{tabular}{|l|c|c|c|c|}
\hline Składnik sił zbrojnych/kraj & USA & Chiny & Rosja & UE (suma) \\
\hline Żołnierze zawodowi [os.] & 1281900 & 2183000 & 1013628 & 1660471 \\
\hline Czołgi & 5884 & 7716 & 20300 & 6264 \\
\hline Samoloty i helikoptery boj. & 3803 & 1808 & 1927 & 2000 \\
\hline Okręty morskie i podwodne & 185 & 441 & 251 & 582 \\
\hline
\end{tabular}

Źródło: opracowanie własne na podstawie danych z raportów SIPRI i GlobalFirepower z lat 2014-2018.

UE zajmuje trzecie na świecie miejsce, posiadając 6,2 tysiąca czołgów, zaraz po Chinach (ok. 7,7 tys.). Pierwsze miejsce należy w tym zestawieniu do Rosji, która obecnie dysponuje aż 20,3 tysiącami czołgów. Ponadto połączone armie europejskie dysponowałyby 2 tysiącami bojowych statków powietrznych (wliczając samoloty i helikoptery bojowe, co daje drugi wynik na świecie po USA) oraz sumarycznie największą liczbą bojowych okrętów morskich, wraz z łodziami 
podwodnymi (łącznie 582 szt.). Biorąc pod uwagę wszystkie powyższe wartości, teoretycznie UE stanowiłaby drugą na świecie siłę militarną i to jedynie na bazie sumy elementów armii, jakimi dysponują poszczególne kraje członkowskie, nie biorąc pod uwagę poziomu zaawansowania technologicznego czy innowacyjności. Nawet pod kątem wydatków na zbrojenia, gdzie niedoścignionym liderem pozostają USA z kwotą rzędu 647 mld dolarów, połączone budżety obronne krajów UE sumowałyby się do kwoty ponad 248 mld dolarów, wyprzedzając Chiny (151 mld dolarów), Arabię Saudyjską (56,7 mld dolarów) i Indie oraz Rosję (po 47 mld dolarów) i stanowiąc drugi wynik na świecie (GlobalFirepower, 2018).

Jednak należy pamiętać, że tak jak zaznaczono na wstępie, nie można obecnie sumować tych wartości, ponieważ siły te stanowią osobne formacje bojowe każdego z krajów, a nie faktyczną siłę zbrojną do dyspozycji UE. Gdyby jednak został wykonany krok w stronę połączenia nawet części wojsk w jedną wspólną armię europejską znalazłaby się ona w pierwszej piątce potęg militarnych świata. Dodając do tego potencjalny rozwój wewnątrzwspólnotowego sektora produkcji zbrojnej, szczególnie w zakresie projektów wielonarodowych, mając w pamięci sukces Airbusa przy produkcji Eurofightera (oraz samolotów pasażerskich, których popularność zaczyna dorównywać samolotom Boeinga), można spodziewać się wykreowania kolejnej militarnej potęgi na arenie międzynarodowej. A z takim statusem UE zyskałaby jeszcze większe znaczenie polityczne oraz większy wpływ na wydarzenia w skali globalnej. Wymagać to będzie jednak trudnego porozumienia członków Wspólnoty w celu stworzenia efektywnie działającego organizmu obronnego.

\section{Polska w relacji z Unią Europejską}

Znaczenie Unii Europejskiej na świecie i jej globalna pozycja pokazuja jak ważne jest budowanie odpowiednich relacji z Brukselą. Polska na tym tle nie ma wiele sukcesów w ostatnich latach, co grozi powolnym separowaniem jej od głównego nurtu europejskiej przyszłości politycznej, gospodarczej i militarnej. UE potrzebuje silnej Polski, jednak $\mathrm{w}$ innym znaczeniu niż jest to dzisiaj przedstawiane przez krajowych polityków partii rządzącej czy liderów ruchów przeciwnych integracji. Siła Polski pochodzi z siły jej obywateli, obejmujących czwartą we Wspólnocie rzeszę studentów (Europa.eu, 2017), a także szerokie grono naukowców oraz ludzi wykazujących się niezwykłą kreatywnością i innowacyjnym podejściem do związywania napotykanych problemów. Wydaje się, że poznanie historii Polski powinno służyć dostrzeganiu pewnych cech Polaków, a przede wszystkim umiejętności radzenia sobie w najtrudniejszych sytuacjach oraz wytrwałości i trwania przy wartościach, na gruncie których zbudowano kulturę Zachodu, nie zaś skłonności do rozpamiętywania męczeństwa, umartwiania się i martyrologii. 
Obecne wyzwania, jakie stoją przed UE to dla Polski szansa, dzięki której może na długo zapisać się w historii Wspólnoty, jako kraj stojący na straży demokratycznych i społecznych wartości, ale też wspierający reformy gospodarcze i zmiany w strefie euro, gdzie może dzielić się swoimi doświadczeniami, wdrażając odważne rozwiązania, które kraje zachodnie z trudem byłyby w stanie opracować właśnie przez brak pewnej perspektywy historycznej. W okresie międzywojennym wzorem dla Europy stały się reformy premiera Grabskiego, które umożliwiły walkę z hiperinflacja, szalejącą nie tylko w II RP. Obecnie Polska także może być wzorem działań w zakresie stabilizacji sytuacji ekonomicznej Europy, ale tylko wtedy, gdy stanie się jednym z liderów zmian, rozpocznie proces wejścia do strefy euro i odważy się przyjąć na siebie ciężar współodpowiedzialności za sprawy Europy. A pierwszym krokiem do takiej pozycji jest praca u podstaw, egzekwowanie zapisów traktatowych, szanowanie zasad trójpodziału władzy, stabilność w zakresie spraw politycznych, społecznych i gospodarczych, a co najważniejsze, przestrzeganie zapisów własnej konstytucji, także w zakresie ochrony własności prywatnej oraz praw obywatelskich. Jeśli te podstawowe warunki zostaną spełnione, to udział Polski w rozwoju UE i jej reformach może być znacznie większy niż dzisiaj ktokolwiek by się tego spodziewał.

Wejście Polski do strefy euro jest o tyle istotne, że jest procesem, który będzie trwał przynajmniej kilka lat, a już dzisiaj mówi się o planowanych zmianach w przyszłych budżetach UE, w ramach których część środków zostanie przesunięta $\mathrm{z}$ obecnie funkcjonujących funduszy (których Polska jest głównym beneficjentem) do funduszu mającego na celu pomoc w przystosowaniu się danego kraju do przyjęcia europejskiej waluty. Chociaż przyjęcie waluty europejskiej jest jedynie kwestią czasu, ponieważ zapisano to wyraźnie w traktatach, to jednak jeśli Polska w kolejnych latach nie zadeklaruje chęci rozpoczęcia procesu wejścia do strefy euro, to mogą ją ominąć pokaźne środki finansowe, jakie być może zostaną przeznaczone na cele konwergencyjne $\mathrm{w}$ najbliższym budżecie UE. A nawet dzisiaj rozpoczęta droga może okazać się długa, ponieważ obecnie Polska spełnia jedynie 2 z 4 wymaganych warunków oraz musiałaby odpowiednio dostosować ustawodawstwo do wymagań traktatowych. W tym względzie Polskę wyprzedzają obecnie Chorwacja czy Bułgaria, które, według raportów Komisji Europejskiej, są lepiej przygotowane do przyjęcia euro, zarówno pod kątem prawnym, jak i pod kątem zrealizowanych wymagań konwergencyjnych (Komisja Europejska, 2018).

Biorąc pod uwagę sytuację migracyjną $\mathrm{w}$ dzisiejszej Europie, warto przypomnieć słowa, jakie Jean-Claude Juncker wypowiedział niedawno w Berlinie: "Jeśli jeden, dwa, lub trzy kraje odstąpią od paktu migracyjnego ONZ, to my, jako Unia Europejska, nie będziemy w stanie bronić naszych interesów" (Gazetaprawna.pl). Był to komentarz do wstępnej deklaracji rządzącej w Bułgarii centroprawicy o odrzuceniu tego aktu, jednak w szerszym znaczeniu wypowiedź ta jest jasnym sygnałem do utrzymywania jedności w UE w najważniejszych sprawach 
politycznych i społecznych. I tej jedności Europa potrzebuje teraz najbardziej. W tym kontekście, Wspólnocie potrzebna byłaby Polska mówiąca jednym głosem z liderami krajów "starej Unii", ale nie jako klakier czy "potakiwacz", ale jako aktywna siła wewnątrzeuropejska, mająca realny wpływ na ustalenia, jakie podejmowane są na najwyższym szczeblu. Historycznie mamy wiele przykładów, kiedy polskie działania polityczne i negocjacyjne prowadziły do tworzenia nowych rozwiązań w obrębie całej Wspólnoty. Jednak był to czas, kiedy Polska była widziana jako lider integracji na obszarze środkowo-wschodniej Europy. Wydaje się, że dzisiaj z oczywistych powodów nie bierze udziału w podejmowaniu niektórych decyzji, a w przypadku innych jej głos jest coraz mniej poważnie traktowany. Liderzy europejskiego federalizmu nadal patrzą na Polskę z nadzieja, licząc na to, że będzie ona "team player'em", a nie "outsider'em" i pomoże zmienić oblicze dzisiejszej Europy. Podkreślał to w 2017 roku Günter Verheugen w jednym z wywiadów, w którym wprost stwierdził, że sojusz niemiecko-francuski przestaje się sprawdzać oraz że pojawia się przestrzeń dla nowych przywódców w UE, a przed Polską stoi ogromna szansa na objęcie pozycji wśród państwliderów Unii Europejskiej (Business Insider, 2017).

\section{Zakończenie}

Zarówno dane statystyczne, jak i logika podpowiadają że siła Unii Europejskiej tkwi w dalszej konsolidacji i pogłębianiu wewnętrznych więzi zarówno gospodarczych, jak i społeczno-politycznych. Na tym tle należy podkreślić, że globalna pozycja Europy jest uzależniona od tego, jakie kroki zostaną poczynione w kierunku formowania wspólnych sił zbrojnych oraz silnej reprezentacji zewnętrznej na politycznej arenie międzynarodowej. Sympozjum "Responses to Joschka Fischer" przyczyniło się do rozpoczęcia szerokiej debaty, w ramach której już przed 18 laty padło pytanie, dlaczego tak trudno nazwać Unię Europejską federacja jeśli spełnia ona większość warunków, by zostać tak nazwaną (Börzel, Risse, 2000). Wydaje się, że wprawdzie Unia Europejska nie spełnia wszystkich warunków i stąd trudno określać ją mianem federacji, jednak ogromna liczba argumentów przemawia dziś za uznaniem, że jedyną droga jaka zapewni Europie realne istotne miejsce na globalnej arenie przyszłości, jest droga ku federalizmowi.

\section{Bibliografia}

1. Borkowski, P.J., Federalizm a budowanie jedności Europy, "Studia Europejskie" nr 2, 2006, s. 87-109.

2. Börzel A.T., Risse T., Who is Afraid of a European Federation? How to Constitutionalise a Multi-Level Governance System, Symposium: Responses to Joschka Fischer, Harvard Law School, Cambridge, 2000. 
3. Business Insider Polska, Verheugen: przed Polska wielka szansa na objęcie przywództwa w $U E$, 2017, https://businessinsider.com.pl/polityka/verheugen-o-pozycji-polski-w-uewywiad/9vs00c2

4. Dahl M., Kuba A., Droga Unii Europejskiej do utworzenia federacji, Journal of Modern Science, tom 4/31/2016, s. 217-236.

5. Deloitte, 2018 Global aerospace and defense industry outlook, 2018, https://www2.deloitte.com/global/en/pages/manufacturing/articles/global-a-and-doutlook.html

6. Duke S., Europe as a Stronger Global Actor: Challenges and Strategic Responses, Palgrave Macmillan, Londyn 2017.

7. ECB, The international role of the euro, Interim report, Lipiec 2018.

8. Europa w obliczu aktualnych wyzwań, [red.] Stępniak A., Borowicz A., Wydawnictwo Uniwersytetu Gdańskiego, Gdańsk 2017.

9. Europa.eu, Living in the EU, 2017.

10. European Commission, A stronger global actor, 2016.

11. Eurostat, The EU in the world, Kwiecien 2018.

12. Gazetaprawna.pl, Juncker: Nawet jeśli jeden kraj UE nie przystapi do paktu o migracji ostabi jej pozycje, Listopad 2018, https://www.gazetaprawna.pl/artykuly/1345234, nawet-jesli-jeden-kraj-ue-nie-przystapi-do-paktu-o-migracji-oslabi-jej-pozycje.html

13. GlobalFirepower, Strenght in numbers, 2018, https:/www.globalfirepower.com/

14. Komisja Europejska - Zestawienie informacji, Sprawozdanie z konwergencji z 2018 r. Przegląd postępów państw członkowskich na drodze do przyjęcia euro, Bruksela 2018

15. ManpowerGroup, 2018 Talent Shortage Survey, Solving the Talent Shortage: Build, Buy, Borrow and Bridge, 2018.

16. Reuters, U.S. dollar share of global currency reserves fall further-IMF, 01.07.2018.

17. Stockholm International Peace Research Institute, różne raporty, 2014-2018.

\title{
THE EUROPEAN UNION AS A GLOBAL PARTNER. WHAT DOES IT MEAN FOR POLAND?
}

\begin{abstract}
Summary
This article presents the challenges facing the EU, and some of the problems it has to cope with in recent years, in the context of the EU's global position among other political and economic powers. It is an attempt to answer the question: what are the most important features that must be achieved by the EU and enables to treat EU as a global partner, and in what areas EU is only at the beginning of the long ride. On this background, there is outlined Poland's possible participation in the EU reform, as well as its current and future position in relation to the EU.

Keywords: European Union, Poland, global partnership, federalism, military potential

JEL Classification: F52, H56, H77, N40
\end{abstract}


Nie kasować nic poniżej tej linii 

